\title{
BET Inhibitor BAY1238097
}

National Cancer Institute

\section{Source}

National Cancer Institute. BET Inhibitor BAY1238097. NCI Thesaurus. Code C121213.

An inhibitor of the Bromodomain (BRD) and Extra-Terminal domain (BET) family of proteins, with potential antineoplastic activity. Upon administration, the BET inhibitor BAY1238097 binds to the acetylated lysine recognition motifs on the BRD of BET proteins, thereby preventing the interaction between BET proteins and histones. This disrupts chromatin remodeling and prevents the expression of certain growth-promoting genes. This leads to an inhibition of tumor cell growth. BET proteins (BRD2, BRD3, BRD4 and BRDT) are transcriptional regulators that bind to acetylated lysines on the tails of histones $\mathrm{H} 3$ and $\mathrm{H} 4$, and regulate chromatin structure and function; they play an important role in the modulation of gene expression during development and cellular growth. 